\title{
PEMBENTUKAN KARAKTER SISWA MELALUI PEMBELAJARAN BAHASA DAN SASTRA INDONESIA
}

\author{
Lis Setiawati (lissetiawati555@gmail.com) \\ Universitas Terbuka
}

\begin{abstract}
Indonesia has a great educational figure whose prominence is not inferior to other world figures. He is Ki Hajar Dewantara. He explicated that education is a means to increase the growth of character (inwardness, character, mind, intellect) of the children, so that the lives of the children are in harmony with their own world. Learning is defined by Knowles (Indah_carapodia.com: 2014) as a way of organizing students to achieve the goal, character is a positive behavior that is done through habit to be formed into a person's character or a learner. Based on these definitions, it can be concluded that education, learning, and character are a unity that can not be separated from one another. Positive behavior that must be trained to students consists of many aspects, one of which is a way of speaking. Therefore, speech training containing positive behavior is the duty of Bahasa Indonesia (Indonesian Language) teachers. Language skills should be trained to students as integrated skills, and not as separate skills. As a professional teacher, establishing the learning strategies which are always associated with character education is no longer a burden. Literature is the representation of human life. Therefore, it is believed that literature is the most appropriate media in instilling positive character for learners. Through professional Indonesian teachers, it is hoped that the younger generations of Indonesia will have a noble character or strong character.
\end{abstract}

Keywords: character, education, language and literature, learning

\begin{abstract}
ABSTRAK
Indonesia memiliki tokoh pendidikan yang kehebatannya tidak kalah dengan tokoh-tokoh dunia lainnya yaitu Ki Hajar Dewantara. Beliau menjelaskan bahwa pendidikan adalah sebuah upaya dalam meningkatkan tumbuhnya budi pekerti (kekuatan batin, karakter, pikiran, intelek) dari tubuh anak, sehingga kehidupan anak didik selaras dengan dunianya. Pembelajaran didefinisikan oleh Knowles sebagai cara pengorganisasian peserta didik untuk mencapai tujuan. Budi pekerti secara operasional merupakan suatu perilaku positif yang dilakukan melalui kebiasaan yang akan terbentuk menjadi karakter seseorang/peserta didik. Berdasarkan dua definisi tersebut tampak bahwa pendidikan, pembelajaran, budi pekerti/karakter merupakan kesatuan yang tidak dapat dipisah satu dengan lainnya. Perilaku positif yang harus dilatihkan kepada peserta didik terdiri atas banyak aspek yang satu diantaranya adalah cara berbicara. Dengan demikian, melatih kemampuan berbicara yang mengandung perilaku positif menjadi kewajiban guru mata pelajaran bahasa (Bahasa Indonesia). Keterampilan berbahasa pun tidak dapat dilatihkan secara terpisah antar satu keterampilan dengan keterampilan berbahasa yang lain. Sebagai guru yang profesional, menyusun strategi pembelajaran bahasa Indonesia yang selalu terkait dengan pendidikan karakter tidak lagi menjadi suatu beban. Sastra adalah gambaran kehidupan manusia. Sastra menjadi media yang tepat di dalam menanamkan karakter positif bagi peserta didik.
\end{abstract}


Melalui guru bahasa Indonesia yang profesional akan terbentuk sebuah generasi muda yang memiliki budi pekerti luhur atau berkarakter kuat.

Kata kunci: karakter, pembelajaran, bahasa dan sastra

Karakter menjadi topik pembicaraan hebat dalam pendidikan kita sekarang ini. Gaung karakter sangat mengejutkan masyarakat khususnya dunia pendidikan. Apa dan ada apa dengan karakter. Menurut Kamus Besar Bahasa Indonesia (KBBI): karakter memiliki arti: 1) sifat-sifat kejwaan, akhlak atau budi pekerti yang membedakan seseorang dari yang lain. 2) karakter juga bisa bermakna "huruf". Pengertian yang sedang dibahas di sini adalah makna kata yang pertama. Berdasarkan makna kata karakter tersebut diketahui bahwa setiap orang memiliki sifat, akhlak atau budi pekerti yang satu dengan lainnya berbeda. Di mana letak perbedaannya? Direktur Jendral Kementerian Pendidikan Dasar dan Menengah (Ditjen Mendikdasmen) Kementerian Pendidikan Nasional menjelaskan perbedaan karakter antar individu yakni: "Karakter adalah cara berpikir dan berperilaku yang menjadi ciri khas setiap individu untuk hidup dan bekerjasama, baik dalam lingkup keluarga, masyarakat, bangsa dan negara. Individu yang berkarakter baik adalah individu yang bisa membuat keputusan dan siap mempertanggungjawabkan setiap akibat dari keputusan yang ia buat". Berkarakter baik menjadi frase kunci bahwa ada orang yang memiliki karakter baik dan ada yang berkarakter buruk.

Seorang guru profesional akan mengerti apa yang akan dihasilkan dari pekerjaan/tugasnya sebagai guru. Jika dengan (penjelasan Mendikdasmen) masih ada guru yang belum dapat memahami apa perannya sebagai guru maka dia harus membuka kembali, membaca, dan memahami bunyi ayat 3 pasal 31 Undang-undang Dasar 1945 (UUD 1945) "Pemerintah mengusahakan dan menyelenggarakan satu sistem pendidikan nasional, yang meningkatkan keimanan dan ketakwaan serta akhlak mulia dalam rangka mencerdaskan kehidupan bangsa yang diatur dengan undang-undang". Jika bunyi butir undang-undang ini dilaksanakan secara konsisten oleh semua guru di semua jenjang pendidikan, mestinya tidak ada sesuatu yang aneh, tidak ada masalah dengan karakter anak-anak bangsa ini. Namun fakta yang terjadi, karakter positif sebagian para peserta didik mulai memudar. Hal ini tampak pada perilaku peserta didik yang kerap melakukan tawuran antar sekolah, hubungan antar lawan jenis yang melewati batas-batas kesopanan, meminum/menggunakan hal-hal yang diharamkan, dan banyak lagi hal yang tidak patut dilakukan. Kita sudah kehilangan adat budaya yang bernilai adiluhung, sama halnya dengan kehilangan jati diri. Berdasarkan hal tersebut pemerintah menyusun undang-undang baru tentang pendidikan bermuatan karakter yakni Undang-Undang Nomor 20 tahun 2003 tentang Sistem Pendidikan Nasional BAB I Pasal 1 ayat 1 berbunyi: "Pendidikan adalah usaha sadar dan terencana untuk mewujudkan suasana belajar dan proses pembelajaran agar peserta didik secara aktif mengembangkan dirinya untuk memiliki kekuatan spiritual keagamaan, pengendalian diri, kepribadian, kecerdasan, akhlak mulia, serta keterampilan yang diperlukan dirinya, masyarakat, bangsa dan negara. Fungsi pendidikan di Indonesia dijelaskan dalam undang-undang ini pada BAB II Pasal 3: "Fungsi Pendidikan nasional adalah mengembangkan kemampuan dan membentuk watak serta peradaban bangsa yang bermartabat dalam rangka mencerdaskan kehidupan bangsa, bertujuan untuk berkembangnya potensi peserta didik agar menjadi manusia yang beriman dan bertakwa kepada Tuhan Yang Maha Esa, berakhlak mulia, sehat, berilmu, cakap, kreatif, mandiri, dan menjadi warga negara yang demokratis serta bertanggung jawab". 
Isi UUD Republik Indonesia tahun 1945 dan UU Nomor 20 tahun 2003 ini sangat jelas menggambarkan ke mana arah pendidikan nasional negara kita. Bila dari sini masih ada guru yang belum memahami tugas-tugasnya sebagai guru, sebaiknya segera menyadari kelemahannya. Belajar dan memahami kembali teori-teori tentang pendidikan dan pembelajaran dan menerapkannya secara konsisten.

\section{Pendidikan dan Pembelajaran}

Sebagai guru bahasa Indonesia, penulis selalu mencari makna sebuah kata melalui kamus besar bahasa Indonesia. Pendidikan berasal dari kata didik yang berarti pelihara dan latih. Kata dasar ini mendapat awalan pe- dan akhiran -an menjadi pendidikan yang dimaknai sebagai proses pengubahan sikap tata laku seseorang atau sekelompok orang dalam usaha mendewasakan manusia melalui upaya pengajaran dan pelatihan. Beberapa ahli dalam Rohman dan Lamsuri (2010: 92) menjelaskan atau mendefinisikan pendidikan sebagai berikut.

Langeveld : Pendidikan adalah pemberian bimbingan dan pertolongan rohani dari orang dewasa kepada mereka yang memerlukan.

Crow and Crow : Pendidikan adalah proses pengalaman yang memberikan pengertian, pandangan, dan penyesuaian bagi seseorang yang menyebabkan ia berkembang.

John Dewey $\quad$ : Pendidikan adalah suatu proses yang membantu pertumbuhan batin tanpa batas usia.

K. Hajar Dewantara : Pendidikan adalah daya upaya untuk memajukan bertumbuhnya budi pekerti (kekuatan batin/ karakter), pikiran (intelek), dan jasmani anak selaras dengan dunianya.

Definisi pendidikan dari empat ahli di atas, tiga diantaranya menekankan pada usaha pertumbuhan batin seseorang. Pertumbuhan batin di sini berhubungan dengan pengembangan budi pekerti atau karakter peserta didik. Tokoh pendidikan kita, K. Hajar Dewantara menyeimbangkan ranah batin dan lahir atau rohani dan jasmani. Unsur batin menjadi perhatian utama dalam pendidikan, menyusul kemudian unsur jasmani.

Begitu pentingnya pendidikan bagi seorang anak manusia. Hal ini kita ketahui melalui firmanfirman Allah berikut ini.

$>\quad$ "Hai Adam, diamilah oleh kamu dan isteri kamu surga ini, dan makanlah makanan-makanannya yang banyak lagi baik di mana saja kamu sukai, dan janganlah kamu dekati pohon ini, yang menyebabkan kamu termasuk orang-orang yang zalim" (QS 2: 35).

Ayat ini mengandung pendidikan karakter/perilaku patuh kepada zat yang memang seharusnya kita taati/terhormat/maha tinggi. Jika di dalam sebuah keluarga (manusia) ayat ini dapat dibaratkan seorang tua yang menasehati anaknya demi kebaikan anaknya kelak. Lihat pula ketika Allah mendidik Yunus dengan memasukkannya ke dalam perut ikan paus.

$>\quad$ "Dan (ingatlah kisah) Zun Nun (Yunus), ketika ia pergi dalam keadaan marah, lalu ia menyangka bahwa Kami tidak akan mempersempitnya (menyulitkannya) maka ia menyeru dalam keadaan yang sangat gelap: 'Tidak ada tuhan selain Engkau, Maha Suci Engkau. Sungguh aku termasuk orang-orang yang zalim" (QS al-Anbiya: 87), dan nasehat Lukman kepada anaknya berikut ini.

$>\quad$ "Dan janganlah kamu memalingkan mukamu dari manusia (karena sombong) dan janganlah kamu berjalan di muka bumi dengan angkuh. Sesungguhnya Allah tidak menyukai orang-orang yang sombong lagi membanggakan dir" (QS. Lukman: 18). "Dan sederhanalah kamu dalam 
berjalan dan lunakkanlah suaramu. Sesungguhnya seburuk-buruk suara ialah suara keledai." (QS. Lukman: 19).

Ayat-ayat tersebut menunjukkan bahwa seperti itulah seharusnya sifat-sifat/perilaku yang dimiliki oleh setiap manusia. Perilaku, tabiat, atau watak yang baik tidak datang dengan sendirinya. Anak, generasi penerus harus dibimbing, dilatih hingga melekat di dalam dirinya. Di rumah orang tua wajib melaksanakan ini, di sekolah guru mengambil alih tanggung jawab ini.

Pendidikan budi pekerti yang sekarang disebut pendidikan karakter merupakan suatu proses di dalam upaya membina budi pekerti peserta didik. Dengan demikian pendidikan memerlukan kegiatan untuk sampai pada tujuannya. Kegiatan memberikan bimbingan, proses, atau upaya tersebut adalah pembelajaran. Robin dan Timothy (2008: 69) mengartikan pembelajaran sebagai perubahan perilaku yang relatif permanen terjadi sebagai hasil pengalaman.

Berkaitan dengan pembelajaran, Peraturan Pemerintah No. 19 tahun 2005 tentang Standar Nasional Pendidikan Bab IV pasal 19 tentang standar proses menegaskan bahwa proses pembelajaran pada satuan pendidikan diselenggarakan secara interaktif, inspiratif, menyenangkan, menantang, memotivasi peserta didik untuk berpartisipasi aktif, serta memberikan ruang yang cukup bagi prakarsa, kreativitas, dan kemandirian sesuai bakat, minat, dan perkembangan fisik serta psikologi peserta didik.

Penjelasan tentang pembelajaran di atas menggambarkan adanya sebuah kegiatan atau proses yang melibatkan pendidik dan peserta didik. Kegiatan tersebut dilakukan untuk mencapai sebuah tujuan yaitu mengubah perilaku, tabiat, sikap peserta didik menjadi lebih baik (berakhlak dan berilmu pengetahuan). Perubahan perilaku secara permanen ini diperoleh dari pengalaman. Dengan kata lain, jika pengalaman menghasilkan perubahan perilaku maka dapat dikatakan sudah terjadi pembelajaran. Jika tidak, jawabannya adalah sebaliknya, tidak pernah terjadi pembelajaran.

Definisi-definisi tentang pendidikan dan pembelajaran di atas sangat jelas menunjukkan tujuan yang mulia bagi setiap anak manusia yaitu memiliki jiwa yang bersih dan baik. Kebersihan jiwa yang baik ini akan membawa manusia pada kehidupan yang baik pula, semakin baik jiwa seseorang akan semakin baik pula kehidupannya. Artinya, seseorang yang berjiwa baik dan bersih akan dapat menjalani kehidupannya dengan tenang, damai, dan tidak pernah mengeluh. Hal ini disebabkan, jiwa yang bersih akan melahirkan pikiran-pikiran yang bersih pula, khususnya bagi kebaikan orang lain bukan untuk dirinya sendiri.

Seseorang yang memiliki karakter baik selalu peduli kepada lingkungannya, kepada masyarakat sekitarnya. Dia akan menjaga kebersihan lingkungannya, dia akan selalu membantu kesulitan teman atau tetangganya, dia mengerti bahwa sebaik-baik kehidupan seseorang adalah yang berguna bagi sesamanya.

Pendidikan budi pekerti atau pembentukan karakter positf bukan hanya tanggung jawab guru agama. Semua guru mata pelajaran, terlebih lagi guru kelas di SD wajib menanamkan pembentukan karakter ini kepada para siswanya (UUD ' 45 dan UU Pendidikan). Tidak ada alasan yang dapat digunakan bahwa pendidikan karakter tidak dapat diterapkan pada mata pelajaran lain, misalnya matematika. Guru yang kreatif dan memiliki karakter baik pasti mampu memasukkan pendidikan karakter di dalamnya. Begitu pula dengan mata pelajaran bahasa Indonesia. Berikut ini uraian tentang model pembelajaran bahasa dan sastra Indonesia bermuatan pendidikan karakter.

\section{Pendidikan Karakter dalam Pembelajaran Bahasa dan Sastra Indonesia}

Setelah memahami definisi-definisi pendidikan dan pembelajaran, seorang guru profesional akan menerapkan pemahamannya di dalam pelaksanaan pembelajaran yang menjadi tanggung 
jawabnya. Tujuan pendidikan dicapai melalui pembelajaran berupa pemberian pengalaman kepada peserta didik. Kendaraan yang mengantar sebuah pembelajaran adalah kurikulum. Oleh sebab itu, perumusan dan penyusunan kurikulum harus dilakukan dengan sangat teliti dan hati-hati. Grand desain atau rancangan besar sebuah pendidikan harus disusun dengan benar. Hal pertama yang harus dirumuskan adalah tujuan. Kendaraan yang membawanya adalah kurikulum, kegiatannya adalah pembelajaran, untuk mengetahui hasilnya adalah penilaian. Kebenaran atau ketepatan hasil yang diperoleh perlu dicocokkan dengan tujuan (pendidikan) yaitu manusia yang berakhlak/berbudi pekerti luhur, cerdas, dan berilmu. Bila dibuatkan diagram alur pencapaian pendidikan adalah sebagai berikut.

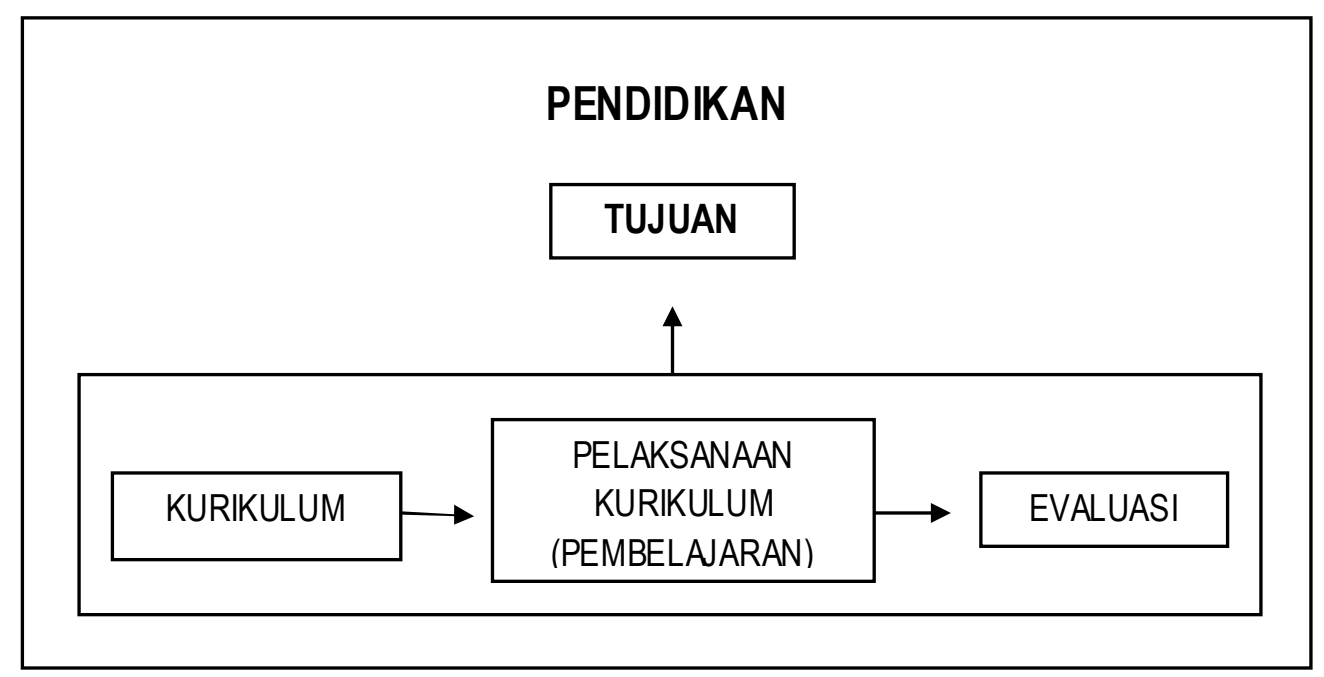

Gambar 1: Komponen dan proses pencapaian tujuan pendidikan

Bagan di atas menggambarkan bahwa untuk mencapai tujuan pendidikan diperlukan adanya sebuah proses pembelajaran. Sebuah pembelajaran memerlukan kurikulum yang berfungsi sebagai pedoman pelaksanaan pembelajaran, untuk mengetahui tingkat keberhasilan sebuah pembelajaran dilakukan evaluasi.

Evaluasi di dalam pembelajaran tidak hanya berfungsi mengetahui hasil belajar peserta didik dalam ranah pengetahuan/kognitif, afektif, dan psikomotor tetapi juga mengukur tingkat keberhasilan guru di dalam melaksanakan pembelajaran tersebut. Dengan demikian, dapat disimpulkan bahwa pembelajaran adalah sebuah kendaraan atau media di dalam mencapai tujuan pendidikan.

Di atas dikatakan bahwa kurikulum berfungsi sebagai pedoman di dalam melaksanakan pembelajaran. Perlu dipahami benar tentang makna kata pedoman; bukan undang-undang. Kaitannya dengan pelaksanaan pembelajaran, kata 'pedoman' di dalam KBBI dimaknai sebagai kumpulan ketentuan dasar yang memberi arah bagaimana sesuatu harus dilakukan; hal yang menjadi dasar untuk menentukan atau melaksanakan sesuatu. Undang-undang adalah ketentuan atau peraturan yang dibuat oleh pemerintah. Dengan demikian undang-undang mempunyai kekuatan yang mengikat. Dari pengertian tersebut dapat kita pahami bahwa pelaksanaan kurikulum di dalam pembelajaran tidak sama dengan pelaksanaan undang-undang di dalam kehidupan masyarakat yang mutlak harus ditaati seperti yang tertulis. Bagaimana peran kurikulum di dalam pembelajaran dapat dilihat pada Gambaran 2. 


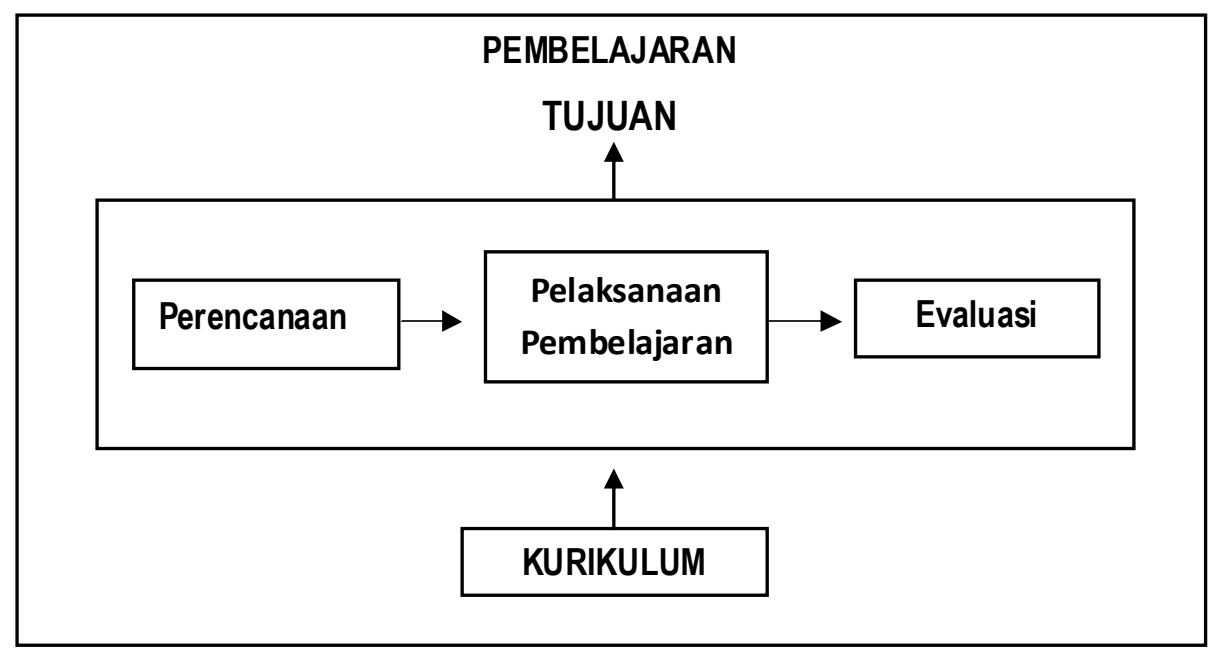

Gambar 2.Kurikulum sebagai pedoman pelaksanaan pembelajaran

Untuk melaksanakan pembelajaran, guru harus membuat perencanaan. Pedoman di dalam membuat perencanaan adalah kurikulum yang berlaku, bukan yang lain. Dengan perencanaan pembelajaran yang matang inilah guru melaksanakan pembelajarannya.

Suatu kegiatan apapun bentuknya bertumpu pada tujuan. Tujuan sebuah pembelajaran berpusat pada peserta didik. Dengan demikian di dalam menganalisis kurikulum, kepentingan peserta didiklah yang menjadi pusat perhatian. Berikut ini beberapa kompetensi inti dan kompetensi dasar Mata Pelajaran Bahasa Indonesia dalam Kurikulum 2013.

\section{Kompetensi Inti dan Kompetensi Dasar Bahasa Indonesia SMP/MTs}

Kurikulum 2013

\begin{tabular}{|c|c|}
\hline Kompetensi Inti & Kompetensi Dasar \\
\hline $\begin{array}{l}\text { Menghargai dan menghayati perilaku } \\
\text { jujur, disiplin, tanggung jawab, peduli } \\
\text { (toleransi, gotong royong), santun, } \\
\text { percaya diri dalam berinteraksi secara } \\
\text { efektif dengan lingkungan sosial dan } \\
\text { alam dalam jangkauan pergaulan dan } \\
\text { keberadaannya }\end{array}$ & $\begin{array}{l}\text { Memiliki perilaku jujur dalam menceritakan sudut } \\
\text { pandang moral yang eksplisit } \\
\text { O Memiliki perilaku peduli, cinta tanah air, dan } \\
\text { semangat kebangsaan atas karya budaya yang } \\
\text { penuh makna } \\
\text { Oemiliki perilaku demokratis, kreatif, dan santun } \\
\text { dalam berdebat tentang kasus atau sudut pandang } \\
\text { Oemilikiperilaku jujur dan percaya diri dalam } \\
\text { mengungkapkan kembali tujuan dan metode serta } \\
\text { hasil kegiatan } \\
\text { Oemiliki perilaku jujur dan percaya diri dalam } \\
\text { pengungkapan kembali peristiwa hidup diri sendiri } \\
\text { dan orang lain }\end{array}$ \\
\hline
\end{tabular}

Pada kompetensi inti di atas tampak adanya muatan karakter (jujur, disiplin, tanggung jawab, peduli, santun, percaya diri, berinteraksi efektif). Indikator ini menjadi pedoman yang harus dicapai di dalam pembelajaran. Beranjak dari kompetensi inti ini guru dapat memilih kompetensi dasar yang 
akan ditanamkan/diterapkan kepada peserta didik. Berlandaskan kompetensi inti dan kompetensi dasar yang telah ditentukan, guru memilih/menetapkan teks yang selaras dengan kompetensi tersebut. Teks tidak hanya sekadar dibaca, dipahami isinya, tetapi juga harus dapat diterapkan di dalam kehidupan peserta didik. Sifat baik/luhur yang sudah diperoleh selalu dilatihkan/dilakukan sampai terbentuk pada diri peserta didik.

Berikut ini contoh skenario pembelajaran bahasa Indonesia bermuatan karakter berbasis teks sastra. Kompetensi dasar ditentukan dengan memperhatikan kesesuaian antara kompetensi inti $\rightarrow$ kompetensi dasar $\rightarrow$ isi teks (kandungan karakter) $\rightarrow$ kemampuan berbahasa.

\section{Kompetensi dasar}

- Memiliki perilaku peduli, cinta tanah air, dan semangat kebangsaan atas karya budaya yang penuh makna

\section{Teks}

\section{Membaca Tanda-Tanda}

\section{Taufik Ismail}

Ada sesuatu yang rasanya mulai lepas dari tangan dan

Meluncur dari sela-sela jari kita

Ada sesuatu yang mulanya tak begitu jelas

Tapi, kini kita telah mulai merindukannya

Kita saksikan udara abu-abu warnanya

Kita saksikan air danau yang semakin surut tampaknya

Burung-burung kecil tak lagi berkicau di pagi hari

Hutan kehilangan ranting

Ranting kehilangan daun

Daun kehilangan dahan

Dahan kehilangan hutan

Kita saksikan gunung memompa abu

Abu membawa batu

Batu membawa lindu

Lindu membawa longsor

Longsor membawa banjir

Banjir membawa air

Air mata

Kita saksikan seribu tanda-tanda

Bisakah kita membaca tanda-tanda

Dengan teks di atas, guru mengajak peserta didik untuk mengungkapkan semua yang ada dalam benak peserta didik. Apa yang tampak oleh peserta didik melalui puisi "Membaca TandaTanda". Perasaan apa yang bisa lahir dari hati peserta didik. Apa yang akan peserta didik perbuat setelah melihat dan menyadari adanya tanda-tanda alam tersebut. Pertanyaan-pertanyaan ini dapat didahului dengan pertanyaan-pertanyaan tekstual/tersurat misalnya:

- Apa warna yang digambarkan oleh puisi tersebut? 
- Bagaimana keadaan danaunya?

- Bagaimana penyair menggambarkan hutan di dalam puisi tersebut?

Masih banyak pertanyaan yang dapat diajukan guru berkaitan dengan makna tersurat puisi tersebut. Pertanyaan-pertanyaan seperti ini mengukur ranah kognitif peserta didik. Pertanyaanpertanyaan berikutnya dapat semakin tinggi yakni menangkap makna tersirat misal:

- Apa yang dimaksud dengan kalimat "gunung memompa abu"

- Apa sebenarnya yang dikisahkan oleh penyair di dalam puisinya?

- Ungkapkan apa yang terbayang oleh kalian ketika atau setelah membaca puisi tersebut? Pertanyaan terus bergeser ke ranah afektif misal:

- Bagaimana perasaan kamu bila menyaksikan keadaan alam seperti yang kalian lihat (melalui puisi) tesebut?

- Jika itu benar-benar terjadi di lingkungan kalian, apa yang akan kalian lakukan?

- Apakah jawaban kalian datang dari lubuk hati atau sekadar membuat Ibu/Bapak guru menjadi senang? dll.

Pembentukan karakter berlanjut pada aplikasi sehari-hari di sekolah (memelihara lingkungan dengan berbagai tanaman, menjaga kebersihan, peduli kepada sesama, dan sikap-sikap mulia lainnya. Karakter baik atau buruk akan terbentuk melalui latihan, kebiasaan, dan usaha yang terus menerus. Seorang guru profesional akan mampu membentuk karakter positif ke dalam diri peserta didik. Tugas ini dilakukan setiap saat di dalam maupun di luar kelas hingga peserta didik tumbuh dan berkembang menjadi generasi berbudi luhur sesuai dengan definisi-definisi pendidikan yang dikemukakan para ahli, sesuai dengan bunyi ayat dalam UUD 45 dan UU Nomor 20 Tahun 2003 mengenai sistem pendidikan nasional.

Masalah pemilihan teks yang sesuai dengan kompetensi merupakan tugas guru. Memang bukan tugas mudah, di sini guru dituntut memiliki perbendaharan teks yang memadai. Setelah memiliki banyak teks untuk digunakan di dalam pembelajaran, guru juga harus mampu menentukan strategi pembelajaran yang tepat sampai pada proses penilaian yang tepat pula.

\section{KESIMPULAN}

Guru profesional, berakhlak mulia, berpengetahuan luas adalah modal utama bagi kemajuan dunia pendidikan kita. Tanpa ini harapan menjadi negara besar dengan bangsa terhormat dan berwibawa hanya akan menjadi angan-angan.

Tugas berat bertumpu di pundak para pahlawan pendidikan. Jika tidak ingin atau tidak sanggup mengemban tugas ini, lebih baik beralih ke profesi lain dengan tugas yang lebih ringan. Thomas Lickona, seorang guru besar pendidikan dari Cortland University (Glock dan Stark, 1966) dalam Ali (2009: 147-148) mengungkapkan bahwa, ada sepuluh tanda-tanda zaman yang harus diwaspadai. Jika tanda-tanda ini sudah ada maka berarti sebuah bangsa sedang menuju kehancuran. Tanda-tanda yang dimaksud adalah: (1) meningkatnya kekerasan di kalangan remaja, (2) penggunaan bahasa dan kata-kata yang memburuk, (3) pengaruh kelompok sebaya (peer group) dalam tindak kekerasan, (4) meningkatnya perilaku merusak diri, seperti penggunaan narkoba dan seks bebas, (5) semakin kaburnya pedoman moral baik dan buruk, (6) menurunnya etos kerja, (7) semakin rendahnya rasa hormat kepada orang tua dan guru, (8) rendahnya rasa tanggung jawab individu dan warga negara, (9) membudayanya ketidakjujuran, dan (10) adanya rasa saling curiga dan kebencian di antara sesama. 
Seorang guru yang selalu menanamkan karakter positif, seorang pemimpin yang baik, seorang pemuda yang berani, atau seorang warga yang peduli pada keberlangsungan hidup bangsa ini dapat menjawab dengan baik pertanyaan: "Sudahkah tanda-tanda tersebut singgah di dalam lingkungan negara kita?" Apakah kita akan diam saja? Kita tidak hancur karena negara, tetapi kita menjadi penyebab hancurnya negara. Keadaan yang menakutkan ini dapat diatasi melalui pendidikan. Untuk itu diperlukan guru-guru profesional. Guru bahasa Indonesia yang profesional mampu membentuk peserta didik yang berkarater positif melalui berbagai teks lisan dan tulis yang tepat dan diolah dengan baik di dalam sebuah pembelajaran.

\section{REFERENSI}

Ali, Mohammad. (2009). Pendidikan untuk pembangunan nasional. Jakarta: Grasindo. Peraturan Pemerintah Nomor 19 Tahun 2005 tentang Standar Nasional Pendidikan.

Robin, Stephen P., \& Judje, Timothy A. (Terjemah: Diana Angelica, Ria Cahyani, \&Abdul Rosyid). (2008). perilaku organisasi organisation behavior. Jakarta: Salemba Empat.

Roman, Arif, \& Lamsuri, Mohammad. (2010). Memahami dan ilmu pendidikan. Michigan University: LaksBang Mediatama bekerja sama dengan Kantor Advokat "Hufron \& Hans Simaela" . (2003). Undang-Undang Republik Indonesia Nomor 20 tahun 2003 tentang Sistem Pendidikan Nasional. 